\title{
Social Welfare Model of Rural Development
}

\author{
Bharat Prasad Badal, PhD \\ Lecturer, Central Department of Rural Development \\ Email for correspondence: bpb@yahoo.com
}

\begin{abstract}
After analyzing the balanced growth unbalanced growth, unlimited supply of laborer, transformation of traditional agriculture and social choice theories as well as Gandhian model of rural development, US market model economy, Chinese socialist's economy, Korean model of rural development (Saemual Undong), mix welfare model of Sweden, this paper emphasizes that people's participation is inevitable to achieve desired development goals. However, all these doctrines, theories or model have identified active participation of the people in development process but still those doctrines are silent about how to emancipate and mobilize people. Here is why, this paper has designed and developed social welfare model of Rural Development (SWMRD) based on Sen's social choice theory, Gandhian model of rural development and doctrine of factors of production of economics. According to the model people have to make plan of their resources for sustainable economic return and its implementation. Government has to assure freedom, human right, motivation and protection. Hence, SWMRD model will be applicable on development studies and useful to development policy makers.
\end{abstract}

Key words: Development, development model, rural development and social welfare model of rural development.

\section{Background}

Development is people's dream of better life. To fulfill one's dream he or she has to work to make it real. It is not the issue of vision or propaganda of political leaders or simply economic issue. Development is a process to understand, where you are and where you want to go. Human beings are different than other biological animal can change the world if he or she is able to mobilize the available resources with human factors. Napoleon, Hitlar or Mahatma Gandhi they were simple human being and able to mobilize other human factor to win the battle. Development is also a kind of battle against poverty and dishonesty among people. Simply honesty is the base of sustainable development. Therefore, people's unity over a dream and action to make it real honestly is development. Government may not be able to reach every nook and corner of people due to its big bureaucratic systems where as market is reluctant to go rural areas. At this critical situation we need neighbors, and neighbor's unity to overcome the situation. It means development practitioners must be able to make a strong people's organization with development dream and plan. So, people will be united for a common goal and achieve that goal with common efforts for common benefit. Social people will be united socially for social welfare officially. These official organizations could be Non-Governmental, not for profit, community-based organizations as civil society.

Non-Governmental Organizations, Civil Society Organizations or Community based Social Welfare Organizations are partner of development that has direct access to the people, resources and government, but they are not free from criticisms that they have to prove accountability and transparency on their every projects and functions (Shrestha, 2009). The state 
led development strategy can play positive and efficient role in macro level development of a country, but state's effort alone is not sufficient for micro level development of a country. On the other hand market led development strategy is getting popular, it focuses on the involvement of the private party in development that is not sufficient either in the accelerating growth or in alleviating poverty of mass people in rural areas of developing country. But private sector does not go for social work or non profitable area. The need of present time is "People Centered" development approach which focuses peoples' need and problem including voice of backward, marginalized, underdeveloped and socially excluded people (Shrestha, 2009). Thus macro level development as devised by Nehruvian sociology that state can do. Market led development seeks profit so hardly the capitalists or investors go to the poor. Thus, SWOs (Social Welfare Organizations) -led development approach is the best suitable development strategy.

\section{Balance Growth theory of Rosenstein Rodan and Ragnar Nurkse}

The main proposition of balanced growth is that there should be simultaneous as well as harmonious development of all sectors through investment that can bring about balance in demand and supply, balance between domestic and international trade, balance among sectors and balance between socio- economic overheads. Nurkse adds underdeveloped countries are engulfed in serious vicious circle of poverty so the cases for balanced growth rest on the need for a balance diet. To cure the underdeveloped economy's vicious circle there should be huge investment in every sector. The economy has to expand market. Private sector is an engine of development while government is driver's seat of engine (Luintel \& Pokhrel, 2011). Many economists have criticized the theory in different way. The theory is prematurely devised but it has given some burning issues on development discourses. The most critical aspect is the theory has not spoken a single word of SWO- Led development approaches. It has not addressed the role of civil society and third sector of development.

\section{Lewis' Theory of Unlimited Supply of Labour}

This model emphasis that labor is an engine of development as well as real source of wealth. It has divided the economy in two sectors as subsistence sector and capitalist sector. The subsistence sector is that part of the economy, which does not use reproducible capital, and capitalist sector is that part of the economy, which does use the reproducible capital. The farmers, the casuals, the petty traders, the retainers, the women in the households and the population growths are the sources of unlimited supply of laborer. The production in expanding capitalist sector takes place according to principle of profit maximization. The per capita output in subsistence sector is smaller than capital sector. The expansion of capitalists sector is depended on subsistence sector. In this school of economic thought, capital and natural resources are highly scares in relation to population. Lewis had clearly mentioned the role of state, private capitalists, savings and bank credit (Luintel \& Pokhrel, 2011). The statements show that the model is also highly criticized anyway it has emphasized the role of subsistence sector. Probably the subsistence sector signifies poor underdeveloped rural section of the economy. However, it has not given any space for the third sector of development. It has completely ignored the social aspect of human development. Subsistence sector should be encouraged, motivated and mobilized by the civil society but the theory has not given any value to the sector.

\section{Unbalanced Growth Theory}

Unbalanced growth theory was propounded by Hirschman, Singer, Rostow, Kindleberger, Streenten with the main theme that the investment should be made in some selected sector rather 
than simultaneously in all sectors of the economy. Prof. Hirschman in his book, "Strategy of Economic Development" the best strategy of development is the creation of imbalance in the economy. Since it is observed that disequilibrium constitute a major step for the progress of the economy as is evidenced by the historical example found in the currently developed countries of the world. Development is a chain of disequilibria that must keep alive rather than eliminate the disequilibrium of which profits and losses are symptoms in a competitive market economy. If economy is to keep moving ahead, the task of development policy is to maintain tensions, misappropriations and disequilibria. Similarly, Benjamin Higgins says, "deliberate unbalancing of the economy in according with a pre designed strategy is the best way to achieve the economic growth". Thus under the imbalanced growth under developed country has to invest continuously on same selected leading sectors. The series of investment can be classified in to two parts as a. convergent series of investment on directly productive area through the investment as capital and profit maximization, divergent series of investment as social overhead capital that the government has to invest is selected areas (Luintel \& Pokhrel, 2011). Thus, this theory also has not addressed the social philanthropic movement and social welfare mode of development.

\section{T. Schultz's Transformation of Traditional Agriculture}

According to noble Laureate Ted Schultz (1902-1989), agriculture sector is an engine of economic development. The contribution of agriculture to economic development lies in: providing more food to the rapidly expanding population, providing raw materials to the industrial sector to import capital goods for the development through the increase of agriculture exports, to increase rural income, providing productive employment and improving the welfare of the mass people etc. Farming based on the kinds of factors of production that have been used by farmers for generation can be called traditional agriculture but it is in the agriculture sector that the better for long-term economic development. Will be lost or won. However, transformation problem is an investment problem. Once there are investment opportunities and efficient intensives, farmers will turn sand into gold. Schultz has also emphasized on investment on human capital that we can develop human resources by learning from experience on the job training and schooling (Kunwar, 2010). This theory has identified human capital, which is most significant in humanity. It has stressed on human resource development but it has not devised the social tools. It has not addressed the human social organization and their significant contribution on development.

\section{Amaratya Sen's Social Choice Theory}

Sen is the first Indian born in 1933 who won the Nobel Prize for economics in 1998 for "an ethical dimension" to the discussion of vital economic problems by combining tools from economics and philosophy. The prize recognized his contribution in the field of social choice theory, welfare economics and economic measurement. His contribution is to make inroads into the assessment of poverty and the evaluation of inequality making possible better social welfare comparisons and changing the way governments prevent and combat famines he had addressed the mean and end of social development is freedom. In democracy information, spread quickly and public criticism comes more easily, making a quick response by the government to extreme event essentials. He opines that social choice theory helps as think more clearly about the meaning of democracy (Kunwar, 2010). The social choice theory advocates the social consequences of the economy and it assumes that democracy is the solution of the entire economic problem but his 
theory is not applicable in uneducated poor community. India, a great democracy in south Asia is herself suffering from underdevelopment. On the other hand, the theory has not contributed in the third sector of economy although he has emphasized on welfare economics and poverty measurement that is very positive praise worthy academic contribution.

\section{Gandhian Model}

The Gandhian view of development is radically different from western model of development. It was based on metaphysical idealism with emphasis on the supremacy of ethical values and moral approaches to the development. It was a plan of political, social and moral reconstruction. The Gandhian model of rural development is a holistic and people centered. It is rooted in his convictions and ideology in tenants of truth, non-violence and goodness of human being with six basic values

- Real India (South Asia) is found not in its cities but in its villages;

- The revival of village is possible by elimination of exploitation of city dwellers is as violence;

- Simple living and high thinking, voluntary reduction of materialistic wants and pursuit of moral and spiritual principles of life is the way of eternity and other happiness;

- Avoiding mechanization for the dignity of labor so that they can earn bread by their physical labor;

- Performance to use of indigenous products (Khadi, Charkha, swadeshi maal), services (Sewa, Dharma, non-violence, truths, humanism) and institution (panchayati swaraj, trusteeship, organization) are most essential and

- $\quad$ There must be good balance between means and ends (Singh, 2009).

Gandhi himself declared Gandhism is no ism, it is only ideology of stateless democracy and he was not a political thinker but a religious minded man who respects for manual labor (Marahatta, 2001). Thus, the model is not systematically developed further more in the opinion of Gandhi, development based on economics and economics alone is no real development. By adopting, an economic growth oriented development path and by following western models of industrialization both under the influence of Jawahalal Nehru, India had abandoned the Gandhian model long ago (Singh, 2009). In such a way, one of the best models of rural development was intentionally ignored and abandoned. Thus, this model was not able to enter as a theory in academia. It is more spiritual than realistic so this model must be developed and modified but the model has advocated reducing the greed and material wants in economy. It has imagined the stateless democracy that completely avoids the role of state in socio economic development. For me, all these theories have not given any substantial space of civil society in economy as academias have respected the importance of civil society organization in economic development.

\section{Discussions over Development Models versus Civil Society}

Rural development is a multifaceted, versatile and multidimensional endeavor. It has different goals and multiplicity of measuring rods to asses it. When there is high expenditure on civic amenities and facilities, we have development. If schools, universities, hospitals, drainage, roads, parks etc are constructed in the villages. Then there is real development that all these things contribute to the well being and welfare of the rural people (Singh, 2009). Thus rural development is multi dimensional approach for the well being and welfare of rural people so different country have adopted different approaches and strategies to meet their goals of rural development. USA 
developed based on a free trade capitalist economy that is market economy. Soviet Union and China developed by diametrically opposed strategy of socialists' ideology of public ownership of property. Sweden adopted a third strategy by combining capitalists and socialist element to create a mixed or welfare economy (Jha \& Jha, 2008). Thus, there are three basic model of economic development they are Market Model, Socialists' Model and Mixed or Welfare Model.

\section{Market Model}

Adam Smith as a self-regulating economy of civil society advised the market Model. It has potential for achieving maximum benefits for all members of society. Here development proceeds without any central direction. It is completely open free market of capitalists' economy. It seeks perfect competition market, freedom and democracy only with profit motive. Prof. J. Patric Gunning from Fen Chai University of Tiwan says, "The market economy is an abstract image of interaction among purposeful, normal human beings or actors, under a given set of conditions. To act purposefully means to have wants and to choose to behave in a way that you believe will satisfy those wants. There are four conditions of the market economy (i. e. a system of private property right, specialization, the use of money and free enterprise). The marketability of an item and its acceptance as money depends on people's expectation that they can exchange this item for valuable goods in the future. The roles of market economy are as it is a resource supplier, producer and consumer".

The French economist J.B. Say in 19th century has propounded the Say's law of Market. That says, "Supply creates its own demand" that mass production creates its own supply with the assumptions as there is no government intervention, the size of market should be capable of expansion, savings are automatically invested, free flow of income and long run operation (Dewett $\&$ Chand, 1997). Still in the present 21 st century people, claim the essence of market economy that still the capitalists concept of market has not been changed. The liberalization, open economy, globalization, deregularization, transformation of the state, decentralization, market economy, market mechanisms, pricing system and privatization are some of the process that have brought new opportunities but also substantiated risks and burden to rural population (Kunwar, 2010). Therefore, being immense importance of freedom and democracy the market model of development is not sufficient itself. Market is also an element of civil society but economists have to prove it. Market as a place, or as a process the main actors are the people and people's organization is civil society. This model is completely incomplete.

\section{Korean Model of Rural Development (Saemual Undong)}

Democratic republic South Korea was established in 1948 with presidential system consisting 16 administrative divisions. The economy is export driven, with production focusing an electronics, automobiles, ships, machineries, petro chemicals and robotics. During the last 25 years, there has been a dramatic reduction of poverty. In 1971, Korean President Park Chung Hee introduced a new model of rural community development. Before that, Korea was one of the least developed countries. It had three years war with north and that had destroyed lives, industrial facilities and even agricultural production bases. In 1961, GDP per capita was only 81 USD. Korean economy has changed dramatically since 1962, when the first five-year economic development plan lunched (Kunwar, 2010). These statements show good plan and programme can bring the substantial change very soon. Saemual Undong was a new village development program. 
At the initial stage, the government provided some materials with financial subsidies to the community people and asked to do something with the subsidy. Government asked the community people to decide what they want to do and to formulate action plan and implement the action plan by community people.

Korean rural community as most other Asian countries have to solve community needs by themselves such as providing primary education facilities, community hall, village roads irrigation system etc. Saemual Undong in Korea is one of the best practices on rural community development, which is replicable for community development in developing countries. Saemual Undong is a community movement to bring spiritual enlightment and betterment of living conditions of people and community in the ways of self-help and operation among community people under the government sponsorship. It is based on the social mechanism of autonomy of the village community, expecting the village people working together in the way of cooperation and self-help for the betterment of village community. Korean model of rural development Saemual Undong has the characteristics as follows. It focuses on community development as a whole. It is operated with community operational mechanism. It takes government-initiating bottom up approach and integrated approach. It is a nationwide campaign to improve community and governance system between community people and local government (Kunwar, 2010). One of the market model economies with a tangible government's intervention in community development is democratic republic Korea. Thus, the model proves the government's assistance in community development is very essential. Similarly, people's participation in local governance is most important. Being a capitalist market oriented economy it has adopted people centered development approach but it has not given any emphasis on people' community based organizations although, it was successful only with the community participation. Thus community based SWO-led development approach has great significance.

\section{Socialists Model}

The Marxist model that Soviet Union, Cuba, North Korea, and China have followed is state based socialistic model. It is based upon the public ownership of means of production and centralization of all sectors of the economy. A central authority or government controls market internally and externally to make all economic decisions. Social welfare is determined by central planning. This model may be called communist state, Marxist state, Leninist state, Stalinist state, Maoists state and many more. Humphery says "Socialism is a system of society in which means of life belongs to community as a whole and are developed and operated by the community with the aims of promoting general wellbeing". Hugan says, "Socialism is a political movement of the working class which aims to abolish exploitation by means of the collective ownership and democratic management of the basic instrument of production and distribution" Emile says "Socialism means the organization of workers for the conquest of political power for the purpose of transforming capitalist property into social property. Indian Leader Jai Prakash Narain says, "Socialism is a society in which all are workers of a class less society. It is a society in which human labor is not subjected to exploitation with interest of private property, in which all wealth is true national or common wealth, in which there are no unearned incomes and no large income disparities and in which human life and progress are planned and where all live" (Dahal, 2005). In this way in Marxist economy, economy is the horse and politics is the cart. The horse always pulls 
the cart back. The theory says the economy first but in practice politics forms the government and government governs the economy. Lenin says Imperialism is the highest stage of Capitalism. Leninism is Marxism in the epoch of imperialism and the proletariat revolution. All these words some time make serious confusions.

\section{Chinese Model of Development (Reforms of Deng Xiau Ping)}

After the dissolution of USSR, Peoples' Republic China is representing the second pole of socialists' polity. As being, a communist state Chinese development is also influenced by the historical, political, and cultural context in which its economic development has occurred. The political events, in leading up to china's decision in 1978 to begin to its economic reforms and the way in which Deng Xiao Ping crafted its new development path. The subsequent extension of Deng's development policies by more recent leader of the Chinese communist party has significant roles. Indicators of Chinese economic progress including its increasing economic openness since 1978 are given and its emerging economic issues and concerns are highlighted (Tisdell, 2009). Thus, Deng Xiau Ping was the charismatic bold leader who determined the new economic policy and now china is the second largest economy. Since 1978, China has experienced extra ordinary institutional change that has proven to be effective in promoting its economic growth and is advancing its international status. It has achieved institutional change in a steady systematic and stayed manner. This is as altered its economic system substantially but its political system has hardly altered. It remains a one party state, which relies heavily on guidance of the leadership of the communist party for its direction. Institutional economic developments of a nation require simultaneous actions on political social and economic settings. Since 1978, the government of China has played very active role in its institutional reforms. Thus, political events have influenced the development of china since last 30 years. The purpose of china's reform was said to be develop socialism with Chinese characteristics. Because of these reforms, china's economy has changed from an economy in which market force played virtually no role in organizing economic activity but one in which these forces play a major role. (Tisdell, 2009). Thus, china has injected liberal market economy in the name of Chinese characteristics in its polity.

As closed communist country china, do not have any special policies to enter modern NGOs. China provides an excellent example of how a rural development strategy focusing on rural industrialization can bring about significant, and mostly positive, change not only in the lives of rural people but also in the structure of the rural economy. China's rural enterprises, widely known as township and Village Enterprises (TVEs) have remarkably contributed to economic growth, rural development and institutional transformation. The Chinese experience is an important area of investigation largely because the huge participation in rural industrialization by rural people resulted in a diversified industrialization over a quarter century. This makes the features of industrialization in China quite successful and different from those of other countries. All such organizations are NGOs, civil society, or peoples' association they had played a significant role in rural development but they are ignored. 


\section{The Mixed Welfare Model}

Welfare state stands against the police state of western capitalists' free world. Dr. Mark Abraham says, "A welfare state is a community where state's power is deliberately used to modify the normal play of economic forces so as to obtain a more equal distribution of income for every citizen". Nehru says, "The fundamentals of a welfare state are equal opportunities for all and raising the standard of living". Hobman says, "A welfare state is a compromise between communism and uncontrolled individualism" (Dahal, 2005). Thus, welfare model is mixed hybrid model designed in between the market and state model ideology. Almost all the countries have some degree of mixed model of development either capitalists or communists. Probably after the downfall of USSR, this model got the space on capitalists' western countries. The model specifies the role of market and state to determine the economy.

Among these three models, it has not fixed the social philanthropic roles. None of these theories or model has included the role of civil society in their contribution. The successful cases are also become successful only with the immense support of grassroots people in different forms and associations. People's organizations like, community forestry program of Nepal, Amual Diary Cooperatives of India, education for nomadic tribes- Van Gujjars in New journey of India, Grameen bank of Bangladesh, Aga khan rural support of Pakistan, Saving and credit cooperative Movement (SANASA) of Sri Lanka, Farmers organization Gal Oya of Sri Lanka etc., are successful program based on people's NGO led development approach (Kunwar, 2010). All these programs prove that I/NGOs are absolute, concrete partner of rural development.

\section{The Model}

A model is coherent scientific arrangement and analysis of facts of a system. Normally system identification of a phenomenon is model building. From the lack of social factors within the specified development model, I am simply identifying a system in between state and market.

\section{Equation}

$\mathrm{RD}=\mathrm{D}$ of (LR) (Rural Development is Development of Local Resources)

$=\mathrm{D}$ of $(\mathrm{NR}+\mathrm{HR}+\mathrm{OR})\{\mathrm{LR}=$ Natural + Human + Other (Resources $)\}$

Where $\mathrm{RD}=$ Rural Development, $\mathrm{D}=$ development, LR $=$ Local Resources, $\mathrm{NR}=$ Natural Resources, HR= Human Resources, and OR = Other Resources

\section{Assumptions}

a. Rural Development is the development of local resources.

b. Local Resources are mix of Natural Resources, Human Resources and Other Resources

c. There are only three active actors in economy as state, market and civil society.

d. State assures freedom, protection and motivation to all stakeholders as a macro level.

e. Market seeks profit and that can take social responsibility through civil society organizations.

f. NGOs or Civil Society Organizations are people's formal, not for profit, autonomous, democratic, non-religious (secular but spiritual), non-political, right base, open, charitable, meets to unmeet organization for social welfare and development in between state and market.

g. Civil societies are micro level people's organization that they can reach every household to listen, feel and develop the people. 
Figure1. Social Welfare Model of Rural Development (RD)

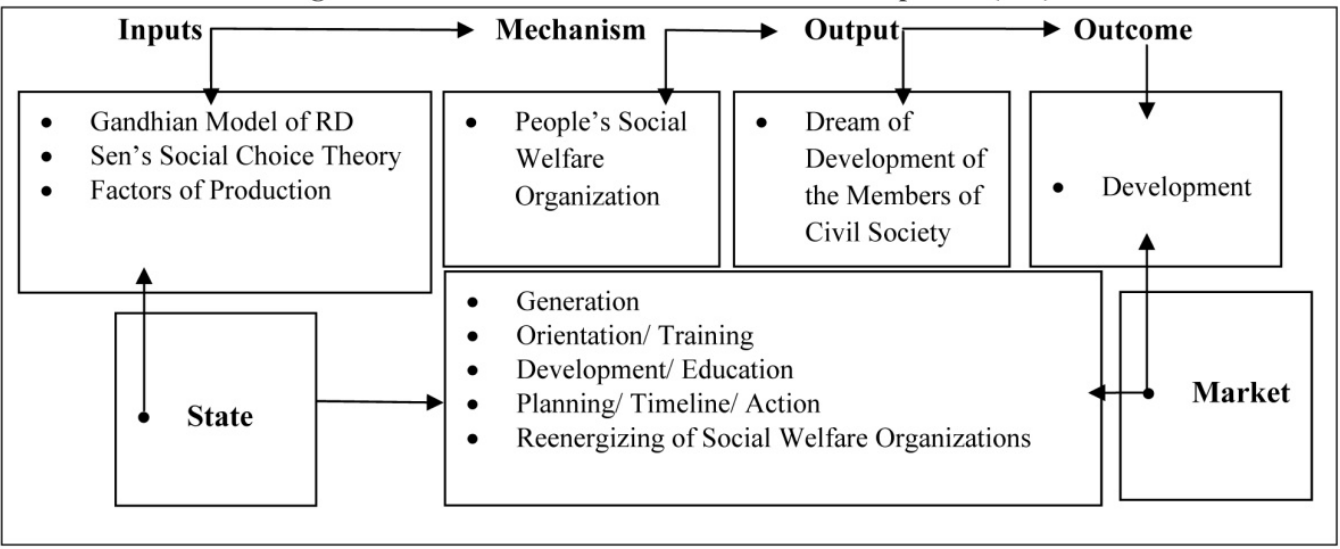

\section{(Developed and Designed by Author).}

The associated legendary works of Gandhi, Sen and various Classical Economists has been associated as follows:

h. Social choice theory of Amaratya Kumar Sen

i. Gandhian Model of Rural Development

j. Doctrine of factors of production of Economics

\section{Justifications}

k. According as the social choice theory of Amaratya Sen the end and the mean of development is Freedom. Therefore, either after or before development freedom is always necessary. At the beginning, people need freedom and right to local resources. Right to local resources means development of local resources for the betterment of people. Thus

Rural Development (RD) = D of LR (Development of Local Resources)

Therefore $\mathrm{RD}=\mathrm{D}$ of $(\mathrm{NR}, \mathrm{HR}, \mathrm{OR})$.

1. From the Gandhian Perspective core value of Rural Development is fulfillment and achievement of Basic needs, self-respect and freedom of village.

Therefore, Rural Development is development on Basic needs, self-respect and freedom.

Therefore Rural Development $(\mathrm{RD})=$ Development of Village

$$
\begin{aligned}
& R D=D \text { of }(\text { Village }) \\
& R D=D \text { of (Village Resources) } \\
& R D=D \text { of (Local Resources) } \\
& \quad R D=\text { Dof (NR, HR, )............... }
\end{aligned}
$$

m. From the principle of Factors of Production of economics, factors of productions are land,

Labor, Capital and organization.

Rural Development is development of rural factors of productions

Rural Development $=$ D of (Land Labor, Capital, Organization)

Where, Land $=$ Natural Resource (NR)

Labor $=$ Human Resource (HR)

Capital and organizations $=$ Other Resources $(\mathrm{OR})$

Therefore $\mathrm{RD}=\operatorname{Dof}(\mathrm{NR}, \mathrm{HR}, \mathrm{R})$. 
From (i), (ii) and (iii)

$\mathrm{RD}=\mathrm{D}$ of $(\mathrm{NR}, \mathrm{HR}, \mathrm{OR})$

Analysis

The dimensions of Civil Societies in Rural Development of Nepal, as great Indian leader Mahatma Gandhi had said that India was to be found not in few cities but in seven hundred thousand villages (Deshmukh, 2012). Similarly, Nepal is to be found in four thousand villages of Rural Nepal. Rural Nepal is out of complete access of central government or election less paralyzed local government and private sectors have not any interest to invest in development due to the lack of profitability. In rural Nepal there is neither government nor private sectors are in effective operation. Development activities should derive through government mechanism with downward accountability. It proves that first sector of development agent government and second sector agent of development private sector both are malfunctioning. Therefore, there is only one sector of development agent for development of Nepal is I/NGOs and I/NGO led development strategy is only solution to develop the rural Nepal in present situation (Shrestha, 2009). Development from top to bottom does not suit the need of people so the idea of Robert Chamber that the bottom up model instead of top down model is appreciable. In the context of Nepal at present transitional crisis, neither government nor private sector can lunch any development programs thus the study focuses as the assumptions that I/NGOs are the milestone of development as third sector.

After the independence-war of India, Gandhi and Neharu separated in their ideology. Gandhi was advocating "Gandhian Model of Rural Development" in India but Neharu be completely influenced by western economic philosophy and power of foreign relation. The first Indian Prime Minister Pandit Jewaharlal Neharu, had introduced the western model of capitalistic state led development because of the colonial hangover, weak foreign relation, disputes with Mahatma Gandhi and proud of administrative power that led twenty years. The direction hold by Neharu was completely imported and exotic influence to sell the dream of development to the poor south Asian people on the perspective of state led capitalistic model of development. Indian National Congress accepted the Neharuvian ideology and the same concept was imported in Nepal because Leaders of Nepali Congress Party were influenced, trained and guided by Indian national congress party. They have also fought on "Bharat Chhodo"- leave India movement. "Neharuvian Socialism" or some similar ideological focus may now be made the scapegoat for the failings of the government led effort in development in several countries (Panday, 1999). The most important fact is that just Trueman spoke it became principle where as Gandhi's ideology was in shadow. Shadowing Gandhi in Indian subcontinent was shadowing the ethics and morality or humanity from economics. Since the inception of democracy in 1950, various models of rural development have been experimented with the assistance of donors and our efforts. The first planned rural development project in Nepal was Tribhuvan Village Development Programme 1952. USAID and later Indian Aid Mission assisted or supported the program (Sharma, 2004). Therefore, to strengthen and stabilize the relation with India and donor agencies Nepalese leaders had accepted the strategies as driven by the donors.

\section{Conclusion}

Different countries had adopted different models of rural development. USA developed

based on a free trade capitalist economy that is market economy. Soviet Union and China developed by diametrically opposed strategy of socialists' ideology of public ownership of

Nepalese Journal of Development and Rural Studies, 14 (1\&2), 2017 
property. Sweden adopted a third strategy by combining capitalists and socialists' element to generate mixed or welfare economy. Korean Model of Rural Development program (Saemual Undong) was a new village development program that government provided some materials and financial subsidies to do something the people utilized that on best way so Korea is a developed country. Similarly, Chinese leader Deng Xiao Ping had lunched new economic policy so the communist China is an economic hub now within last 30 Years. China's rural enterprises, widely known as Township and Village Enterprises (TVEs) have remarkably contributed to the economic growth, rural development and institutional transformation. Whether in capitalistic, socialistic or mixed economy people's participation is must. Theoretically, balanced growth theory of Rodan and Ragner, Lewis' theory of unlimited supply of laborer, unbalanced growth theory of Hirschman, Singer, Rostow etc., Ted Schultz's transformation of traditional agriculture have completely ignored social philanthropic model of rural development. Hence, this review paper concludes that ignoring the transformative role of civil society is the most amazing facts for rural development. In this context, SWMRD will be a pioneering development model of 21 st century. The central part of this model is people and their associations for their betterment. The main theme of the study is pure social philanthropic social welfare organization of general people in civil society in full strengths can develop their society according as their pre-determined goals. State, Market and other third sector development partners must be able to unite, motivate, dream and implement accordingly to the general people of the society. Thus, this model can be included in developmental curricula of Tribhuvan University.

\section{References}

Dahal, R. (2005). Rural Development Politics in Nepal. Kathmandu: Dikshanta Pustak Bhandar.

Deshmukh, S. P. (2012). Gandhian Vission of Rural Development. International Reffered Research Journal, 24-26.

Dewett, K. K., \& Chand, A. M. (1997). Modern Economic Theory. New Helhi: Shyam Lal Charitable Trust.

Jha, U. D., \& Jha, N. D. (2008). Economics of Rural Development. International Journal of Rural Studies, 50-62.

Kunwar, K. B. (2010). Rural Development in Developing Countries (Policies, Strategies and Practices). Kathmandu: Meena.

Luintel, C., \& Pokhrel, K. (2011). A text book on rural development theories, approaches \& methods. Kathmandu: Pradhan Book House.

Marahatta, P. (2001). Global Political Thought. Chitwan, Nepal: S. Koirala.

Panday, D. (1999). Nepal's Failed Development Reflection on the Mission \& the Maladies. Kathmandu: Nepal South Asia centre.

Sharma, P. (2004). Local Development Planning in Nepal an Emperical Experience. Kathmandu: Kshitiz Publication.

Shrestha, M. (2009). Community Development. Kathmandu: Quest Publication.

Singh, K. (2009). Rural Development Principles Policies and Management. Delhi: Sage Publication.

Tisdell, C. (2009). Economic Reform and Openness in China: China's Development Policies in last 30 Years. Economic Analysis and policy,39. September, 271-294. 